\title{
Towards a Future Scenario for Offshore Wind Energy in Chile: Breaking the Paradigm
}

\author{
Cristian Mattar ${ }^{1, *}$, Felipe Cabello-Españon ${ }^{1}$ and Nicolas G. Alonso-de-Linaje ${ }^{1,2} \mathbb{D}$ \\ 1 Laboratory of Geosciences, University of Aysen, Aysén 5950000, Chile; fcabello.e@gmail.com (F.C.-E.); \\ s202316@student.dtu.dk (N.G.A.-d.-L.) \\ 2 DTU Space, Technical University of Denmark, 2800 Kognens Lyngby, Denmark \\ * Correspondence: cristian.mattar@uaysen.cl
}

Citation: Mattar, C.;

Cabello-Españon, F.;

Alonso-de-Linaje, N.G. Towards a Future Scenario for Offshore Wind Energy in Chile: Breaking the Paradigm. Sustainability 2021, 13, 7013. https://doi.org/10.3390/ su13137013

Academic Editor: Domenico Mazzeo

Received: 13 May 2021

Accepted: 17 June 2021

Published: 22 June 2021

Publisher's Note: MDPI stays neutral with regard to jurisdictional claims in published maps and institutional affiliations.

\begin{abstract}
Offshore wind energy continues to be a potential candidate for meeting the electricity consumption needs of the Chilean population for decades to come. However, the Chilean energy market is skeptical about exploiting offshore marine energy. At present, there are no offshore marine energy farms. This is probably attributable to the current legal framework, payback period, initial costs of inversions, and future wind speed trends. This work aims to break this paradigm by advancing knowledge regarding the main issues concerning offshore marine energy in Chile. To this end, we estimated the Levelized Cost of Energy (LCOE) from 2000 to 2054 using the CMIP RCP 4.5 and 8.5 climate projections. These projections were based on the estimations for a $608 \mathrm{MW}$ offshore wind project located along the Chilean coast. A comprehensive analysis of the legal framework for implementing offshore marine energy is also presented. The results show that the LCOE ranges between 24 USD/MWh and $2000 \mathrm{USD} / \mathrm{MWh}$. Up to $80 \%$ of the study area presents favorable results. Future climate scenarios did not affect the project's economic viability and notably indicated two major zones with low interannual variability. In terms of legal frameworks, there is a gap in a Chilean trans-ministerial law that ends up causing several processes to be duplicated. Further research is needed to reduce the uncertainties associated with offshore wind energy generation on the Chilean coast. This study aims to further knowledge related to both the opportunities and challenges associated with offshore wind.
\end{abstract}

Keywords: offshore wind energy; Chile; future scenarios; climate change

\section{Introduction}

Because of current trends in global energy consumption, the scenarios for future energy demand have garnered a great deal of attention. On a global scale, offshore wind energy has grown rapidly, with over $29 \mathrm{GW}$ of installed capacity existing in Europe (75\%) and China (23\%), who are the market leaders [1]. In fact, Europe has a long history of investment and support of offshore wind energy development and expects that by 2030, the offshore wind energy potential will exceed its current goal of about 76 GW [2]. These facts have led to special attention being given to offshore wind energy assessments in other continents in recent years, demonstrating great potential in North and South America, Asia, and Africa, among others [3-10].

The offshore wind industry still has a low installed worldwide capacity compared to onshore wind and solar photovoltaics, which have 621 and $509.3 \mathrm{GW}$, respectively [1,11]. One reason for this difference is that offshore wind energy is a capital-intensive technology, which gets reflected in higher prices [12]. For instance, up to $75 \%$ of its lifetime cost can be an upfront investment [13].

Nevertheless, the current state of the offshore wind market relies on government subsidies to maintain the competitiveness of wind projects. This is the case of feed-in tariffs (FIT) subsidies, which can range from $0.12 \mathrm{USD} / \mathrm{kWh}$ in the case of China, to up to $0.3 \mathrm{USD} / \mathrm{kWh}$ in Japan [14]. 
Several mechanisms for promoting the spread of this technology by governments have been observed, such as investments and policies like the FIT, progressive tax, Renewable Portfolio Standards (RPS), and low-interest loans [15]. In addition to market maturity [16], these mechanisms have encouraged a consistent and incremental growth in the offshore wind market over the last few decades, reaching 6 GW of installed capacity in 2019 alone [1]. In 2020, cost reduction continues to be a necessary and expected part of developing a competitive offshore wind energy industry $[17,18]$. Indeed, the Levelized Cost of Energy (LCOE) for offshore wind energy has decreased steadily in the last decade [19]. This decline in LCOE values is attributable to several factors: an increase in project size, a continued optimization of technology, the installation processes used, and an improved market regulatory framework [20-22]. Consequently, offshore wind energy has become an attractive energy source for other countries which have adopted the experiences of world leaders in the form of new installations and assessments of their own offshore wind energy potential. For instance, the United States is starting to increase its investment in offshore wind energy to become a world leader, as it has more than $2000 \mathrm{GW}$ of offshore wind capacity and a development goal of $25 \mathrm{GW}$ of installed capacity by 2030 [1,23]. Furthermore, in South America, offshore wind energy has gained more attention during the last decade in Colombia [24,25], Brazil [26-28] and Chile, which has almost 4,000 $\mathrm{km}$ of coastline [9,29].

In Chile, the possibility of future impacts arising from climate change has led to several legal and political changes with regards to renewable energy generation [30]. The main legal modifications were aimed at creating a goal of $20 \%$ electric energy generation by 2025 [31]; the renewable energy requirements on the electric generation industry (e.g., RPS) and the long-term milestone for Chilean energy sets a goal of $70 \%$ generation by renewable sources by 2050 [32]. Moreover, recent research is starting to increase knowledge about Chile's offshore wind and wave energy potential. For instance, Mattar and Villar-Poblete [29] conducted an initial work about offshore wind energy potential using satellite and reanalysis data. Mattar and Guzmán-Ibarra [9] gained the first insights into perspectives on technical and economical offshore wind energy, examining aspects such as a nationwide LCOE, Net Present Value (NPV), Internal Rate of Return (IRR), and Pay-Back (PB). However, several modeling assessments have been performed on the great potential of marine energy in Chile, such as the nearshore wind-wave energy resource in central Chile using numerical models [33-35]. The initial wind potential maps provided by the Ministry of Energy in Chile deserve special attention, as they bridge the gaps in onshore wind energy, despite retaining information in terms of offshore wind potential [36].

The Chilean National Energy Commission (CNE) makes a database available of national installed capacity in terms of renewable energy, energy generation, and future energy demands. By 2019, Chile had a national installed capacity of nearly $25.3 \mathrm{GW}$, of which $5 \mathrm{GW}$ corresponded to either wind or solar energy generation [37]. Additionally, a steady increase is expected in Chile's energy demand over the following 20 years, rising from $71.6 \mathrm{GWH}$ in 2019 to $108.9 \mathrm{GWh}$ in 2039, equivalent to an annual rate of about $1.95 \mathrm{GWh}$ per year [38]. Currently, land-based wind energy represents $18 \%$ of the national installed capacity of renewable energy (Figure 1). 


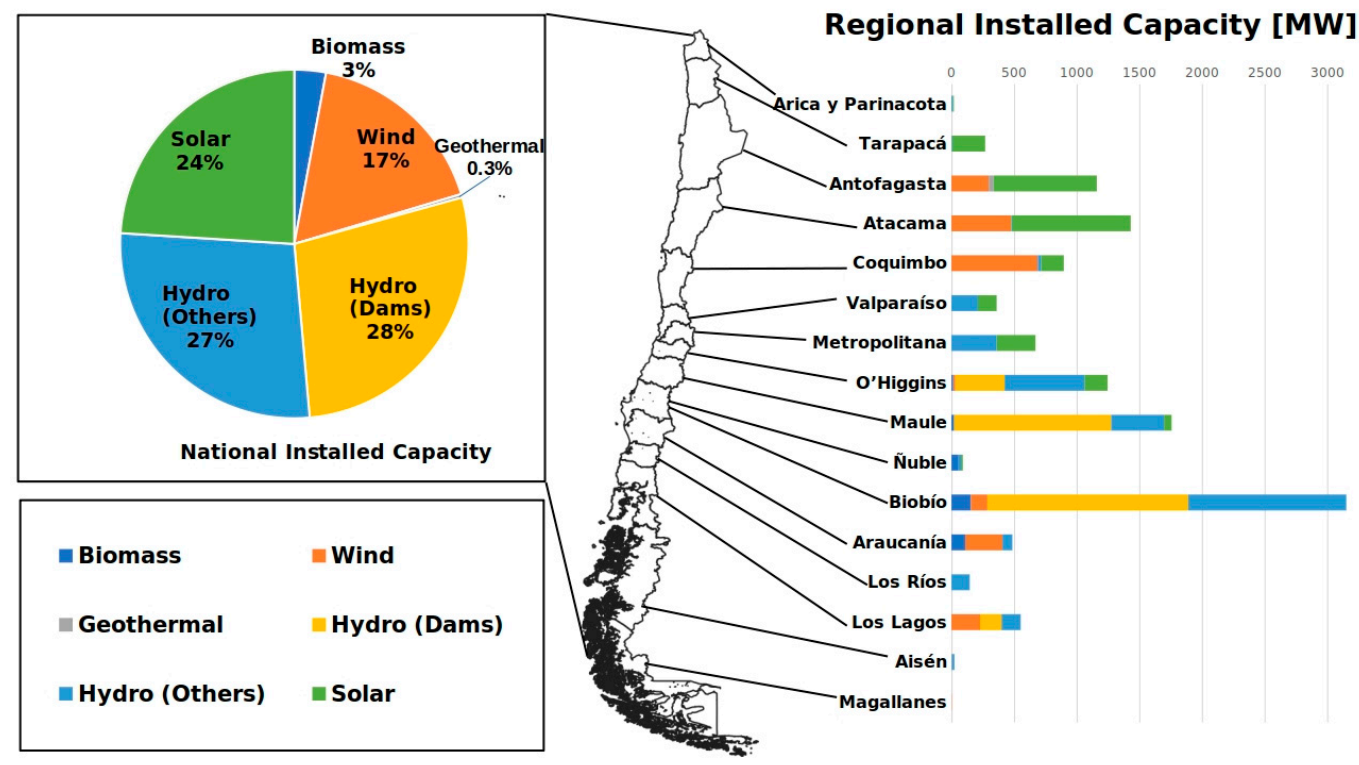

Figure 1. Percentage of national installed capacity of renewable energy (left) and regional installed capacity of renewables in MW [37].

Despite the advances in offshore wind energy potential and the improvements in the legal framework of renewable energy generation, there are still no offshore wind projects in Chile. New sources of information about offshore wind perspectives based on potential, resource assessments, and LCOE generate potential scenarios to develop this technology. In this sense, this manuscript assesses the high cost of installing an offshore wind farm, coupled with insufficient knowledge about LCOE. These factors are the main paradigm that raises economic skepticism regarding this technology in the country. As such, there are some strategies that could change the government incentives for mitigating the investment risk on marine renewable energies and strengthen the current trends in Chilean offshore wind energy. Knowing what must change could make a difference in terms of the investment incentives for offshore wind. To this end, this work aims to identify how future prices are associated with climate scenarios with regard to offshore wind energy exploitation. This work also contributes to further decisions regarding offshore wind projects in Chile. The manuscript is structured as follows: Section 2 presents the study area, Section 3 describes the data and methodology used, Section 4 shows the results and analysis of the information, Section 5 presents the discussion, and Section 6 provides the relevant conclusions.

\section{Study Area}

The study area encompasses the Chilean coast between $18^{\circ}-56^{\circ} \mathrm{S}$ from the coastline, up to the limit of the Exclusive Economic Zone (EEZ) (200 nautical miles) (Figure 2). This area was selected for the wind energy potential demonstrated by Mattar and GuzmanIbarra [9] and Mattar and Villar-Poblete [29]. These works assessed the techno-economic viability of an offshore wind installation and the offshore wind potential in the study area. In this area, the institutional jurisdiction for offshore wind projects falls to the ministries of Energy, Defense, and Economy and the environmental legal frameworks. Namely, the Ministry of Energy regulates the bidding process and the technical norms pertaining to Chile's energy system through the National Commission of Energy (CNE) [39]. The Ministry of Defense controls the use of the territorial sea, seabed, and beaches [40]. Through the undersecretary of fisheries and aquaculture, the Ministry of Economy manages the offshore project and its spatial relation to other economic activities already approved near the offshore project zone [41]. Finally, through the Environmental Assessment Service 
(SEA), the Ministry of Environment verifies the fulfilment of the environmental standards and the life-cycle of the project [42].

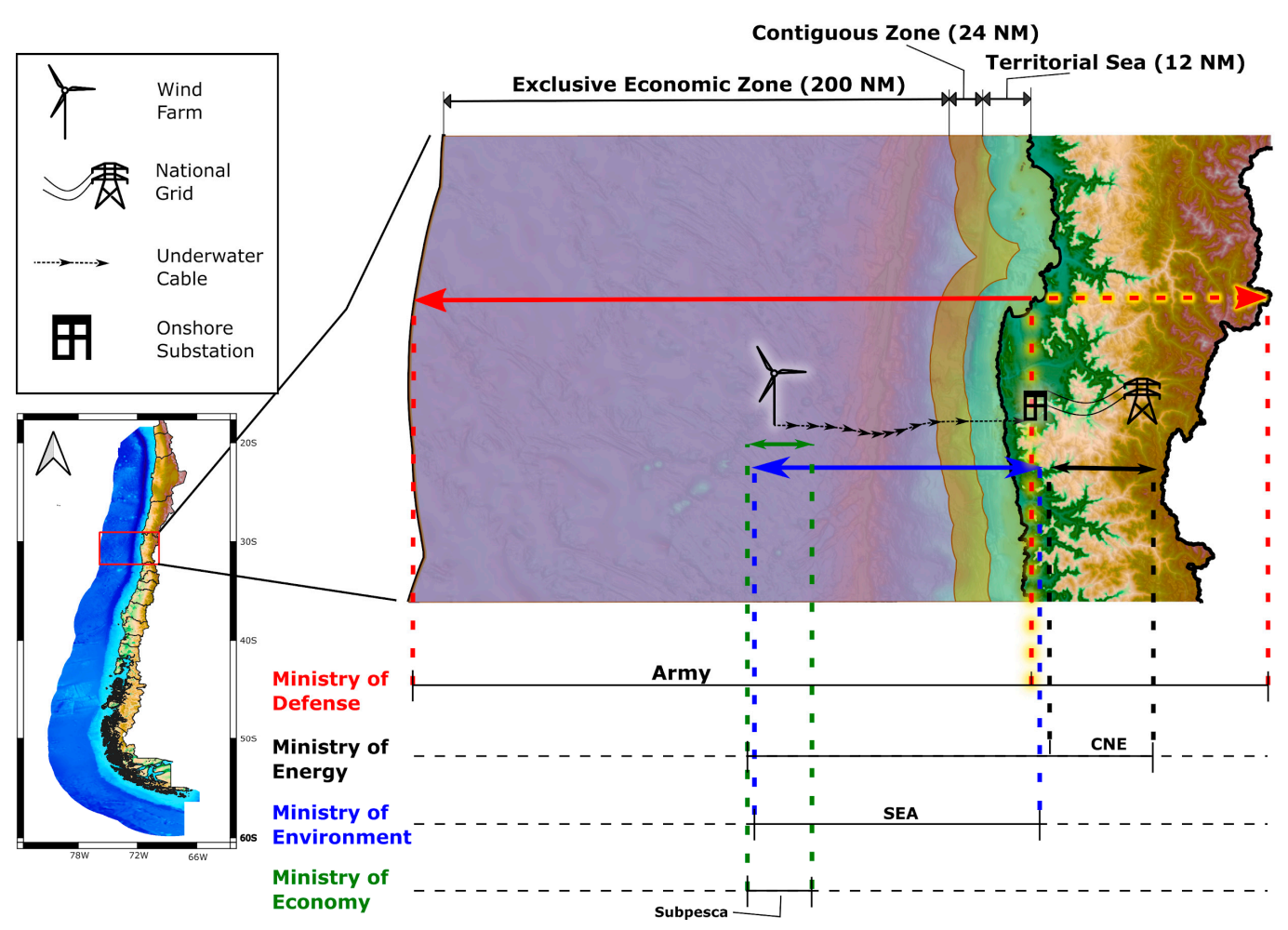

Figure 2. The study area presented with the different marine zones and legal framework ministries. At the top are the three different categories of sea jurisdiction measured in nautical miles (NM). At the bottom, the extent and legal overlap of the four ministries regulating the offshore projects.

\section{Data}

\subsection{Data from ERA5 and CMIP5}

The wind speed data provided by the ERA5 reanalysis was used. Starting in the year 2000 and continuing through to 2020 , the " $10 \mathrm{~m}$ wind speed" component was used, corresponding to the monthly average horizontal speed of the wind at the height of $10 \mathrm{~m}$ [43]. The future projections of wind data were extracted from the Climate Model Intercomparison Project-Phase 5 (CMIP5) multimodel archive of climate simulations. The CMIP5 RCP future climate projections on near-surface wind data considered in this work are from the HadGEM2-CC model of the UK Meteorological Office, and its horizontal resolution is around $1.25^{\circ}$ in midlatitudes [44]. Future wind data was taken from future climate projections of two RCPs: RCP 8.5 is a "business as usual" emission scenario, characterized by rising GHG emissions and high concentration levels of these gases in the atmosphere. RCP 8.5 can be seen as the projection of future GHG concentration and radiative forcing if no emissions mitigation strategies are employed until the end of the 21st century. RCP 4.5 is a midrange stabilization scenario, where GHG emissions are mitigated by policy actions, strategies, and technologies employed to achieve emission targets before 2100 [45-47]. For both RCPs, the time window is between 2020 and 2050.

\subsection{Technical and Economic Data}

The technical and economic data available in the study conducted by Beiter et al. [48] were used as the primary source of costs for an offshore wind project. This study is a spatialeconomic cost-reduction analysis for the offshore wind industry on the U.S. territorial sea, developed by the National Renewable Energy Laboratory (NREL). Such work was used due to its extensive documentation regarding each stage of an offshore wind project. It 
contains information on both technical and economic data regarding the different stages of a project and how some environmental variables can impact the final pricing of the energy produced.

The main expenditures related to offshore wind energy are broadly classified into capital expenditure (CapEx) and operational and maintenance expenditure (OpEx) [13]. This includes the amount of cash invested upfront for the initial expenditures of the project and the ongoing costs of both operating and maintaining the project to keep it operational. All relevant stages for the development, installation, operation, and decommissioning of an offshore wind project, as well as their approximate costs, are presented in Table 1. Bathymetry and distance to shore will impact the final capital expenditure and operational expenditure values. For this reason, two maps were used as variables to evaluate the spatial variability of the study area. The cartography generated by the Global Ocean \& Land Terrain Model [49], presented in 15 arc-second intervals, was used to determine the water depth values for every pixel. Similarly, a map of geodesic distances to the mainland was generated on GIS software to determine the distance of each pixel to the cable landfall. For any given location, there will be taken into consideration both the water depth and distance to shore. This information is critical to account for the cost variability regarding the installation and acquisition of the project and its substructures, and the length of the electrical system.

Table 1. The costs of a $600 \mathrm{MW}$ offshore wind project by category and types [48].

\begin{tabular}{|c|c|c|c|}
\hline Cost Category & Category & Cost (USD/kW) & Note \\
\hline Turbine & CapEx & 1583 & - \\
\hline Development & CapEx & 196 & - \\
\hline Ports and Staging & CapEx & 25 & - \\
\hline Operations & OpEx & 31 & - \\
\hline Substructure & CapEx & Variable & Dependent on water depth \\
\hline Assembly and installation & CapEx & Variable & $\begin{array}{l}\text { Dependent on the distance } \\
\text { to land and water depth }\end{array}$ \\
\hline Electric System & CapEx & Variable & $\begin{array}{l}\text { Dependent on the distance } \\
\text { to land }\end{array}$ \\
\hline Maintenance & OpEx & Variable & $\begin{array}{l}\text { Dependent on on-site } \\
\text { specific features }\end{array}$ \\
\hline $\begin{array}{c}\text { Engineering and } \\
\text { Management }\end{array}$ & CapEx & Multiplier & $\begin{array}{l}3.5 \% \text { multiplier applied to } \\
\text { the total value of CapEx }\end{array}$ \\
\hline $\begin{array}{l}\text { Insurance during } \\
\text { Construction }\end{array}$ & CapEx & Multiplier & $\begin{array}{l}1 \% \text { multiplier applied to } \\
\text { the total value of CapEx }\end{array}$ \\
\hline Commissioning & CapEx & Multiplier & $\begin{array}{l}1 \% \text { multiplier applied to } \\
\text { the total value of CapEx }\end{array}$ \\
\hline Installation Contingency & CapEx & Multiplier & $\begin{array}{c}30 \% \text { applied to installation } \\
\text { CapEx and 5\% to } \\
\text { non-installation CapEx }\end{array}$ \\
\hline Procurement Contingency & CapEx & Multiplier & $\begin{array}{c}5 \% \text { of } \\
\text { non-installation CapEx }\end{array}$ \\
\hline Decommission & CapEx & Multiplier & $65 \%$ of installation CapEx \\
\hline
\end{tabular}

\section{Methodology}

\subsection{Wind Energy Estimators from CMIP5 Data}

Wind power was estimated through the method proposed by Weibull [50,51]. The area under the probability density function $f(V)$ curve is called the cumulative distribution function. Therefore, the Weibull cumulative distribution function can be found by 
taking an integral of $f(V)$, denoted by $F(V)$. Both functions are given in Equations (1) and (2), respectively:

$$
\begin{gathered}
f(V)=\left(\frac{k}{c}\right)\left(\frac{V}{c}\right)^{k-1} \exp \left[-\left(\frac{V}{c}\right)^{k}\right] \\
F(V)=1-\exp \left[-\left(\frac{V}{c}\right)^{k}\right]
\end{gathered}
$$

where:

$V=$ Wind speed $\left(\mathrm{m} \mathrm{s}^{-1}\right)$

$k=$ Shape Weibull parameter $(-)$

$c=$ Scale Weibull parameter $\left(\mathrm{m} \mathrm{s}^{-1}\right)$

The wind power density and wind power were obtained by Equations (3) and (4), assuming a value of air density $(\rho)$ of $1.225 \mathrm{Kg} \mathrm{m}^{-3}$.

$$
\begin{gathered}
W P D=\frac{P}{A_{T}}=\frac{1}{2} \rho V^{3} \Gamma\left(1+\frac{1}{k}\right) \\
W P=\frac{1}{2} \rho A_{T} V^{3} \Gamma\left(1+\frac{1}{k}\right)
\end{gathered}
$$

$W P D=$ Wind Power density $\left(\mathrm{W} \mathrm{m}^{-2}\right)$

$W P=$ Wind Power $(W)$

$\rho=$ Air density $\left(\mathrm{Kg} \mathrm{m}^{-3}\right)$

$A_{T}=$ Rotor area of the wind turbine $\left(\mathrm{m}^{-2}\right)$

$V=$ Wind speed $\left(\mathrm{m} \mathrm{s}^{-1}\right)$

$k=$ Shape Weibull parameter (-)

$\Gamma=$ Gamma function

For the purpose of estimating rotor area, the wind turbine model Vestas V-164 9.5 MW was considered. This is one of the most powerful wind turbines on the market and has a hub height and diameter of 110 and $164 \mathrm{~m}$, respectively [52]. To estimate Wind Energy Generation (WEG), the average annual power $\left(P^{*}\right)$ of the Vestas V-164 9.5 MW was considered, in addition to the period during which this wind turbine is working. The WEG formula is denoted by Equation (5).

$$
W E G=P^{*} T
$$

where:

$W E G=$ Wind Energy Generation (MWh)

$P^{*}=$ Average annual power of the Vestas V-164 9.5 MW wind turbine (W)

$T=$ Period of generation time (hours)

\subsection{Spatial Trends of WEG}

In this work, a well-known method for trend detection, the Mann-Kendall test, was implemented $[53,54]$. This is a non-parametric method frequently used to detect trends in climate data [55-58].

$$
S=\sum_{i=1}^{n-1} \sum_{j=i+1}^{n} \operatorname{sgn}\left(x_{j}-x_{i}\right)
$$

The significance ( $p$, quantified at the 0.05 level) of the trends in the WEG anomalies time series was evaluated with the Mann-Kendall (MK) test [53]. 


\subsection{Inter-Annual Variability of WEG}

The temporal variability of WEG was analyzed by different descriptive statistics, including minimum (Min), maximum (Max), range (R), and standard deviation (S). Furthermore, the inter-annual variability (IAV) represented by Equation (7), was quantified following the approach proposed by [59].

$$
I A V=\frac{\sigma}{W E G_{m}}
$$

where:

$I A V=$ Inter Annual Variability (-)

$\sigma=$ Standard Deviation of WEG (MWh)

$W E G m=$ Mean of WEG (MWh)

\subsection{Economic Analysis}

The LCOE was the central metric used to determine the economic potential of offshore wind in the study area. To compute the LCOE values, the methodology presented by Short et al. [60] was used (Equation (8)). These values are dependent on distance to shore, water depth, and wind speed.

$$
L C O E=\frac{I \times F C R}{Q} \times \frac{O \& M}{Q}
$$

where:

LCOE: Levelized cost of energy (USD/MWh)

$I$ : Initial investment (USD)

FCR: Fixed-charge rate

$Q$ : Annual output (MWh)

OEM: Annual operation and maintenance costs (USD)

The annual output of energy $(Q)$ corresponds to the total energy production in a given year. It depends heavily on both the on-site wind speed behavior and the wind turbine model used as a reference. Beiter et al. [48] used a $600 \mathrm{MW}$ project with $6 \mathrm{MW}$ turbines as a reference, using the "Openwind" package from AWS Truepower to calculate energy output. Due to the differences in methodology and the fact that Beiter et al. [48] has cost references for $10 \mathrm{MW}$ turbines, the decision was made to keep the size of the project within a similar range but using available information. The V164-9.5 MW Vestas turbine model [52] was used to compute the values of $Q$, keeping the size of the hypothetical offshore wind project at $608 \mathrm{MW}$.

Most of the information presented by Beiter et al. [48] is absent on local sources, most likely due to a lack of experience regarding offshore wind power generation in the Chilean context. To offset the lack of local information it is assumed that the economic behavior presented by Beiter et al. [48] will be similar to the study area. Therefore, the same equations are used to calculate cost. The main emphasis is made on the environmental differences between the Chilean and U.S. coast; mainly water depth, wind speed, and distance to shore.

Both the initial investment (I or CaPex) and the operation and maintenance costs $(O \& M)$ vary greatly according to changes in water depth and distance to shore. The location of the assembly site and staging port will influence the cost of the offshore project. Additionally, the distance to the coast will determine the composition of the electrical system, as well as the use of an offshore substation. It is assumed that the assembly site, the staging port, and the underwater cable landfall are located at the nearest site on land. A 33-kV system is used when the project is up to $9 \mathrm{~km}$ away from shore; when the project is between 9 and $115 \mathrm{~km}$, a 220-kV system is used; above $115 \mathrm{~km}$, a HVDC system is used. Bathymetry values will define the kind of substructure used in the project. For up to $80 \mathrm{~m}$ of water depth, a fixed-bottom substructure was used. For deeper waters, a floating substructure is needed. Since the floating substructure cost data were not disclosed by 
Beiter et al. [48] due to confidentiality, the acquisition costs presented by Bjerkseter and Ågotnes [61] were used. Because most of the pixels in the study area represent a water depth greater than $80 \mathrm{~m}$ [49], the floating substructure model was mainly used. However, some nearshore sites have shallower waters, allowing for the use of fixed substructures.

Some of Chile's economic metrics were used to better model the behavior in the study area. The tax rate used was $25 \%$, corresponding to a "First category taxing rate" [62]. The discount rate used corresponds to an $8.74 \%$ discount for "wind energy technology actives", issued by the Chilean Ministry of Energy [63].

\subsection{Economic Variability}

It is expected that the LCOE will decrease over time; the study of Valpy et al. [64] was used as a reference to reflect this decreasing trend. In it, the impact of 57 technology innovations on the LCOE of offshore projects is evaluated, anticipating up to a $36 \%$ decrease in the LCOE by 2030. Based on the NREL's annual technology baseline, a cost decrease in line with a logarithmic fit lasting through to 2050 is assumed [65].

Similarly, the study of IRENA [12] on renewable generation costs was used as a reference to simulate the potential variability in costs between the year 2000 to 2020. It was assumed that the behavior of the LCOE of the project would be similar to the changes seen in the average cost of electricity in the offshore wind market. The Consumer Price Index (CPI) was used to estimate the current value of LCOE between the years 2000 and 2020 (using 2020 as a base year). For future estimations, a steady 2 percent inflation rate was used, this being the mean inflation rate of the previous two decades. Figure 3 presents the general flowchart of this work.

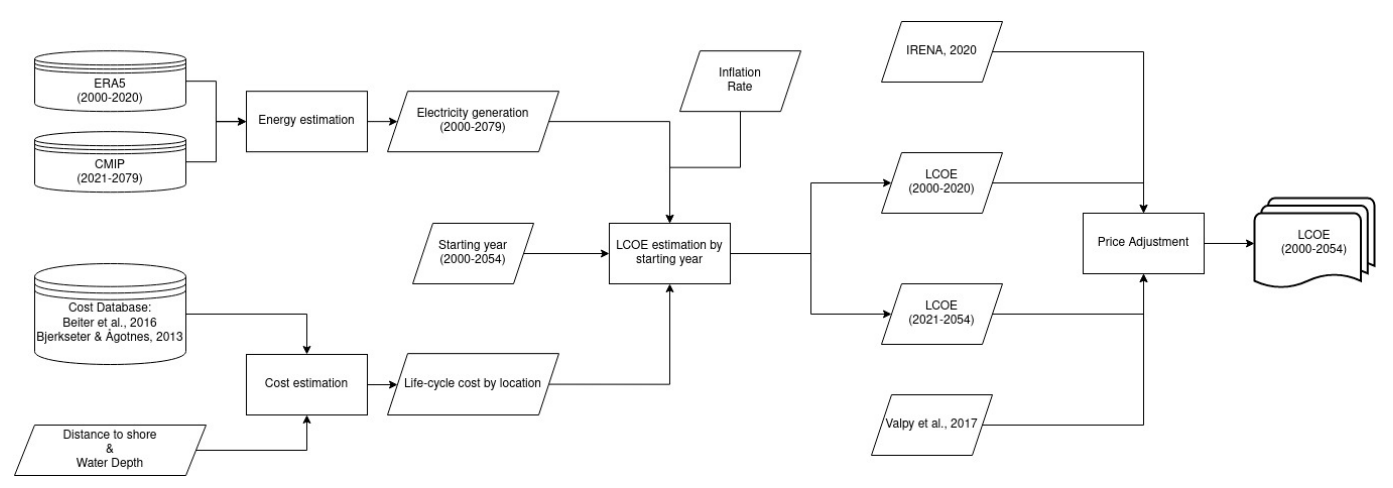

Figure 3. General flowchart for LCOE estimation.

\section{Results and Analysis}

5.1. Inter-Annual Variability (IAV) of WEG

The results of the WEG interannual variability for the RCP 4.5 and 8.5 future scenarios show similar values in the south of Chile between $42^{\circ}-54^{\circ} \mathrm{S}$ (Figure 4). There, the IAV is relatively low, with changes ranging from $30 \%$ to $50 \%$, which means that the WEG will not change very much even if the most severe scenario is reached. Regarding central Chile between 30 and $42^{\circ} \mathrm{S}$, it is possible to observe the highest IAV in the RCP 4.5 scenario with changes above $90 \%$ in both far and near offshore locations. On the other hand, in the most severe scenario, the IAV values are lower, ranging between $60 \%$ and $80 \%$. This means that in principle, a more severe climate change scenario does not imply a more significant interannual change in the WEG for the coasts of central Chile. Finally, for northern Chile between 18 and $30^{\circ} \mathrm{S}$, the lower interannual changes are observed near the coast in the RCP 8.5 scenario, with IAV values ranging between $20 \%$ and $30 \%$. In both cases, the highest values are near the coast and around $70 \%$. 


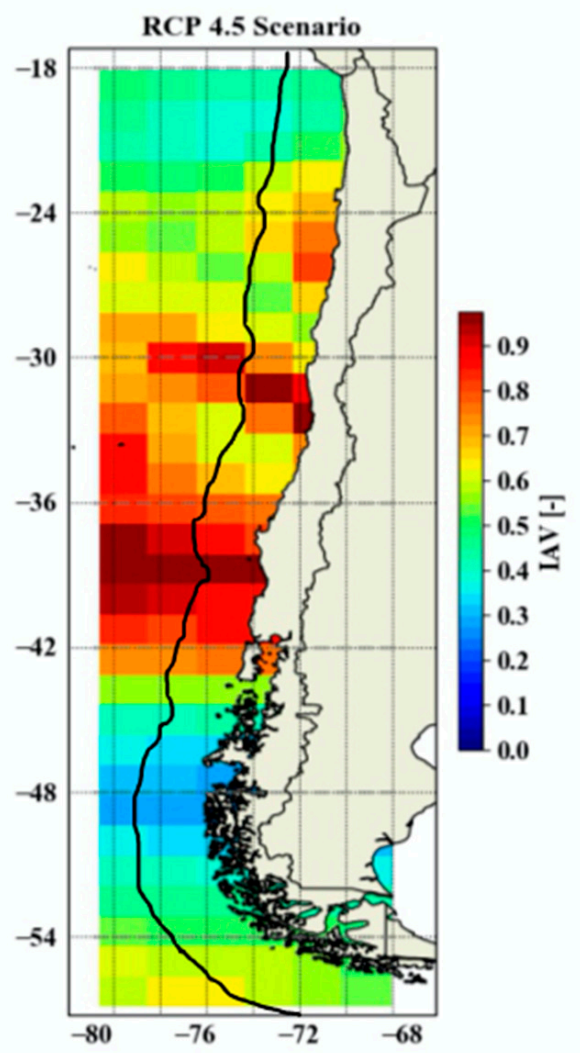

(a)

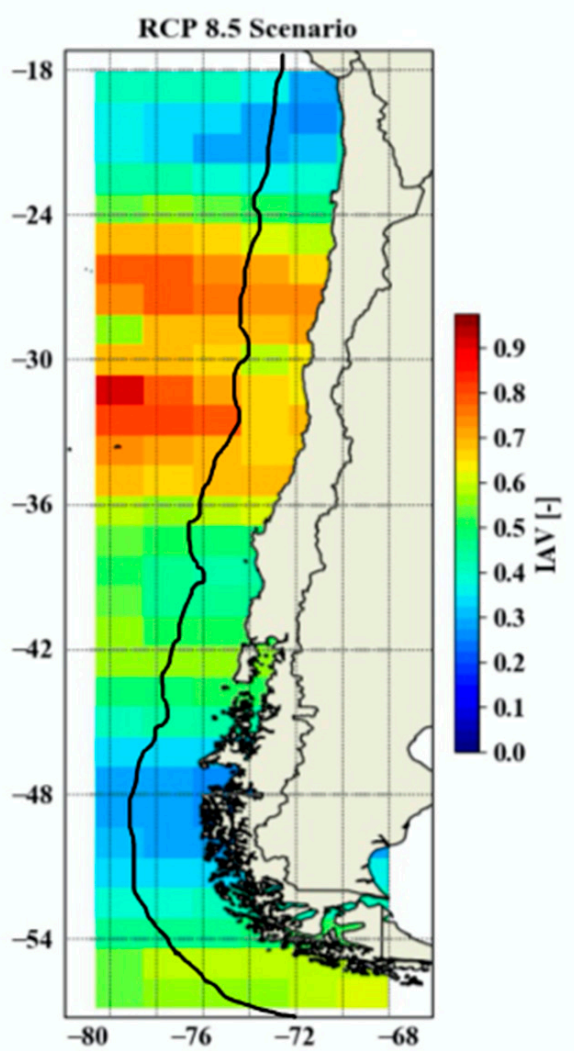

(b)

Figure 4. Interannual variability of WEG for 4.5 (a) and 8.5 (b) RCP future scenarios between 2020 and 2054

\subsection{Spatial Trends of WEG}

Regarding the spatial trends of the WEG, the only significant trends near the coast are observed in the 4.5 scenario in central Chile (Figure 5). Therefore, for the most severe scenario, two significant trend areas are observed both in southern and northern Chile. Those trends are, however, in the far offshore range. In northern and central Chile, significant trends indicate an increasing WEG, whereas for the significant trend in the area of southern Chile, a decrease of WEG is observed.

\subsection{LCOE and the Energy Legal Framework}

The Levelized Cost of Energy (LCOE) results show significant variability in the price of energy in the study area (Figure 6). The values obtained ranged from 24 USD/MWh to almost 2000 USD/MWh in some sectors. Most of the sites with the least viable economic potential were concentrated in the central zone between $33^{\circ}$ and $41^{\circ} \mathrm{S}$. Figure 3 presents the evolution of the LCOE according to its starting year of production and the representative concentration pathway (RCP) projected. 


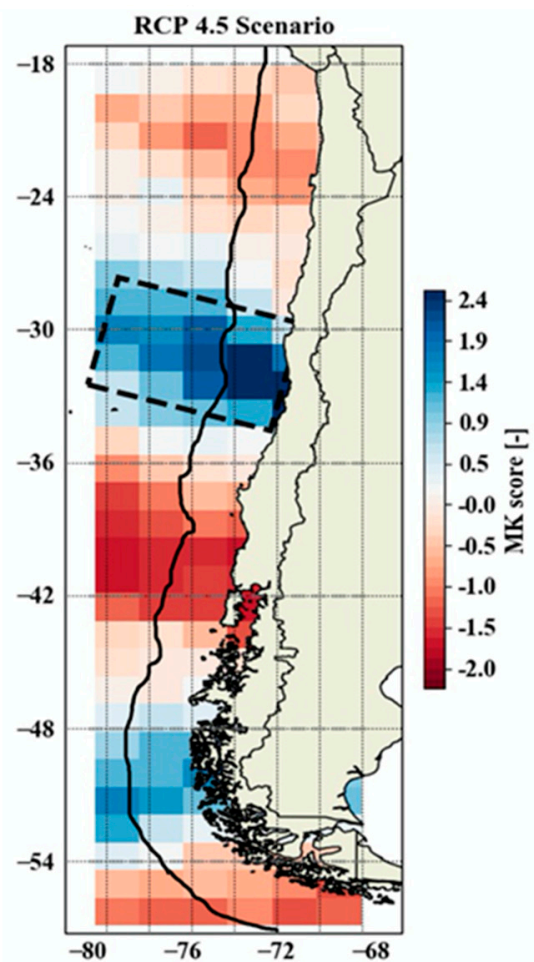

(a)

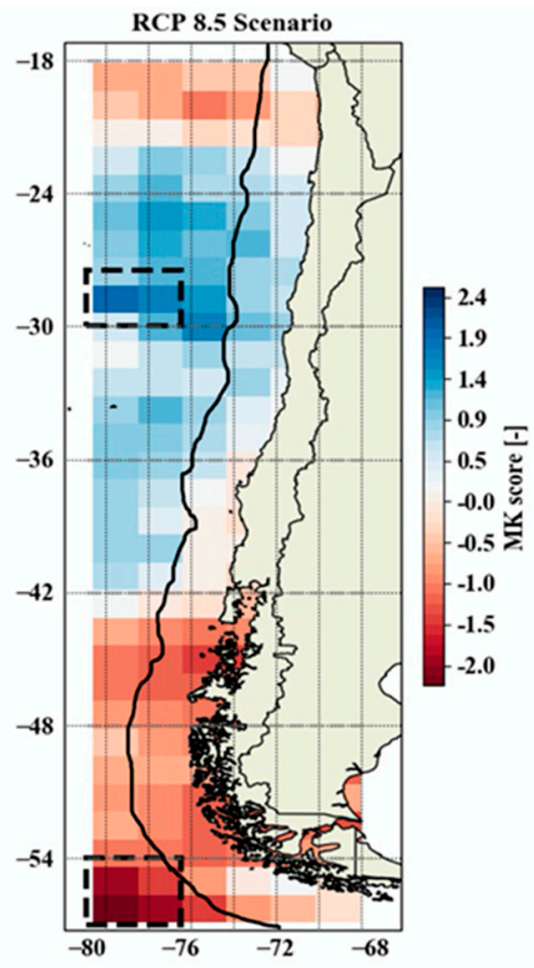

(b)

Figure 5. Mann-Kendall trends for wind energy generation between 2021 and 2051 for the RCP 4.5 scenario (a) and RCP 8.5 scenario (b).

There was a general decrease in LCOE values in RCP 8.5 and RCP 4.5 trajectories over the projected years (2021-2054). While the decrease in LCOE was more significant in the RCP 8.5 scenario, both followed a similar trend in cost reduction. This reduction was significantly driven by the decrease in CapEx and OpEx presented by Valpy et al. [64] and Hundelberry et al. [66]. The results obtained have some similarities to the data presented by Mattar and Guzman-Ibarra [9]. In said research, the southern part of Chile showed the most promising results regarding economic viability due to high wind speed. However, the northern part of the country had no competitive LCOE values, unlike what is shown in the current results. The differences can be attributed to the different sources of information used regarding the wind turbine model, wind speed, and cost dataset.

Zones with high wind speed and low LCOE could be profitable for installing an offshore wind farm and even supported by the legal framework of the Chilean state. However, several constraints have been taken into consideration related to the Chilean legal framework for energy projects (Figure 7). The offshore project can partake in the bidding process regulated by the CNE [39] as an "unconventional renewable energy project", directly competing with other energy projects. To be able to do so, it must be approved by the ministries of Energy, Defense, and Environment. For example, the Ministry of Defense manages the coastal and sea activities through the emission of "maritime concession" [40]. To be able to function within the legal boundaries, an offshore wind farm would have to be granted a "major maritime concession" due to having a time span longer than ten years. This procedure can have a duration, by law, of up to 180 business days. 

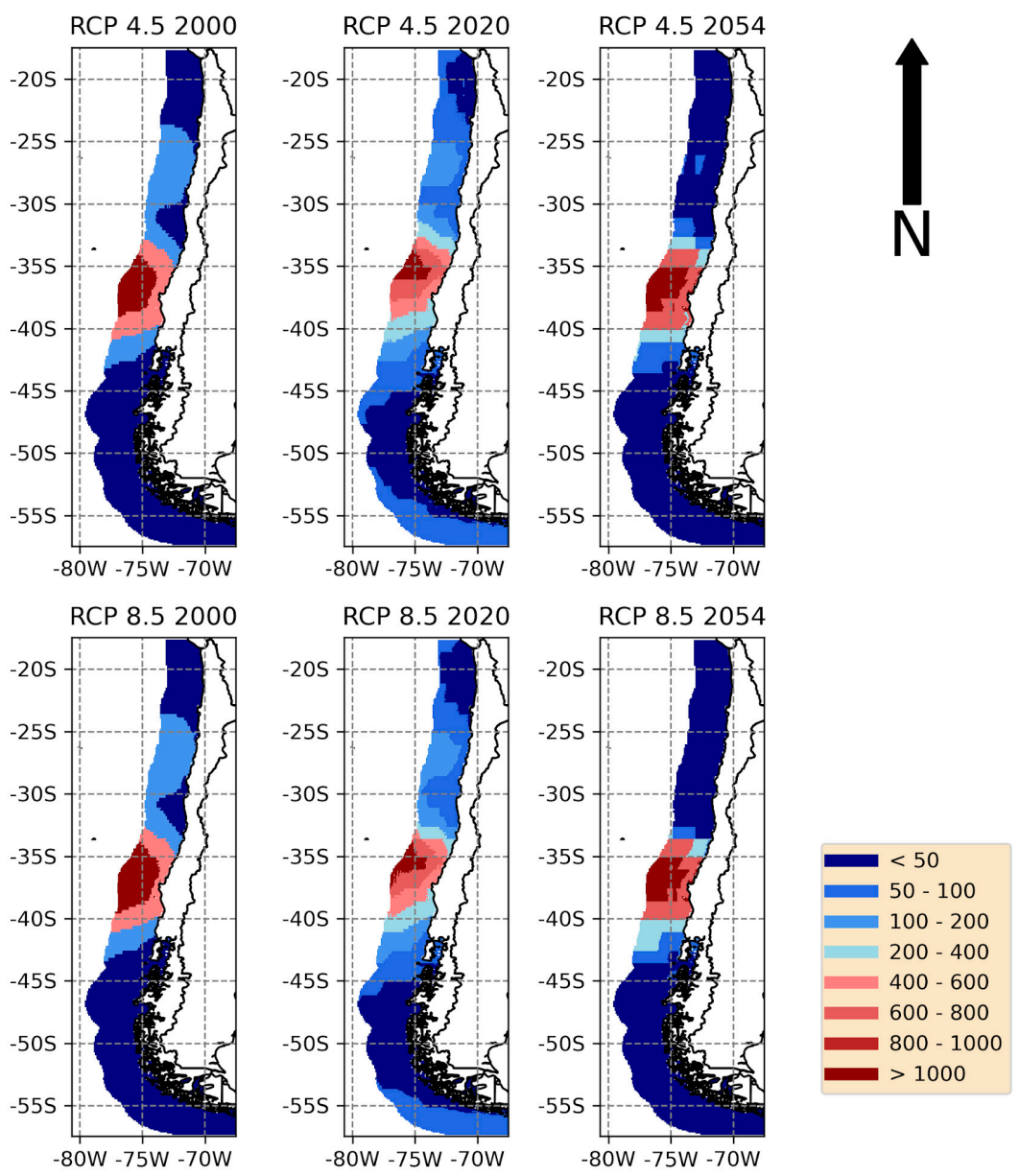

Figure 6. LCOE (USD\$/MWh) spatial variability according to starting year $(2000,2020,2054)$ of production and RCP $(4.5,8.5)$.

Additionally, the SEA has to grant a favorable environmental qualification resolution (RCA), showing that an environmental impact assessment was performed, and the impacts are within the legal limits [42]. The granting of the RCA is a multi-part procedure involving many other public institutions and can have a timespan of well over 300 business days. It's important to emphasize that both the issuance of the favorable RCA and the major maritime concession are entirely independent processes, and the granting of one does not legally guarantee the granting of the other. Consequently, an offshore wind project becomes a high-risk investment due to the lack of both incentives and coordination of the public institutions that deal with offshore energy projects. 


\begin{tabular}{|c|c|c|c|c|c|}
\hline The race & Bidding Process & Maritime concession \& Environmental Approval & Construction aproval & Construction starts & Connection to Grid \\
\hline$\rightarrow \rightarrow$ & & & 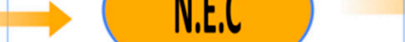 & & $\rightarrow$ \\
\hline $\begin{array}{l}\text { Technical and Economical } \\
\text { feasibility of the project } \\
\text { is assessed }\end{array}$ & $\begin{array}{l}\text { The project is presented } \\
\text { through the bidding process } \\
\text { as a new installation }\end{array}$ & $\begin{array}{l}\text { An environmental impact assessment is presented to the S.E.A. for approval. } \\
\text { An application for a major maritime concession y presented to the local port captaincy. } \\
\text { The approval of both organisms is necessary to continue the process. }\end{array}$ & $\begin{array}{l}\text { A requestis sent to the National energy commission (N.E.C.) } \\
\text { regarding the intiation of the construction phasefor th the project. }\end{array}$ & The project is ready to start its construction. & $\begin{array}{l}\text { Once the construction is ready the project may start to sell energy } \\
\text { according to the contract defined in the bidding process. }\end{array}$ \\
\hline Stakeholders & $\begin{array}{l}\text { - National distribution companies } \\
\text { - Ministry of energy } \\
\text { - National Energy Comission }\end{array}$ & $\begin{array}{l}\text { - Ministry of defense - Local Port captaincy - Ministry of environment } \\
\text { - Environmental Assessment Service (E.AS.). - Local communities (Through public consultation) } \\
\text { - Public services with environmental competence }\end{array}$ & $\begin{array}{l}\text { - Ministry of energy } \\
\text { - National Energy Comission (N.E.C.C.) }\end{array}$ & $\begin{array}{l}\text { - Owner } \\
\text { - Local communities } \\
\text {-Publicinspection bodies }\end{array}$ & $\begin{array}{l}\text { - Ministry of energy } \\
\text { - National Energy Commission (N.E.C.) }\end{array}$ \\
\hline Legal framework & $\begin{array}{l}\text { - Exempt decree } \mathrm{N}^{\circ} 106 \text { by the } \\
\text { Energy Ministry (2017) } \\
\text { - Exempt decree } \mathrm{N}^{\circ} 373 \text { by the } \\
\text { National Energy Commission (2020) }\end{array}$ & $\begin{array}{l}\text { - Decree } N^{N} 40 \text { by the Ministry of environment (2013) } \\
\text { - Decree } N^{\circ} 9 \text { by the Ministry of National Defense (2018) }\end{array}$ & $\begin{array}{l}\text {-Exempt decree } N^{0} 659 \text { by the Ministry of energy \& } \\
\text { the National Energy Commission (2016) }\end{array}$ & & $\begin{array}{l}\text { - Decree with force of law } \mathrm{N}^{\circ} 4 / 20018 \text { by the Ministry of economy, } \\
\text { development and reconstruction; under secretary of economy, } \\
\text { development and reconstruction (2007) }\end{array}$ \\
\hline 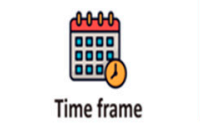 & Low & Hioh & Low & Medium & \\
\hline
\end{tabular}

Figure 7. Legal race for any marine renewable project in Chile. 


\section{Discussion}

This work provides new economic insights and fills gaps in environmental data, such as bathymetry along the coast of Chile. However, there still remains a lack of clarity in terms of the investment costs for an offshore wind project in Chile based on the current political framework for legal energy. The offshore wind energy that sits untapped as a source of energy in the current Chilean coast energy paradigm exceeds the current demands of the national market and is fairly competitive compared to the mean market price [67]. Exporting energy from the region could be a potential market to develop offshore wind energy in Chile. Indeed, the region of Central and South America has a projected energy demand increase of 26.9 TWh per year [19]. This could be a future opportunity for expanding the current energy production of Chile to other countries using offshore wind energy as a source.

Most of the economic information used in this study relies on prior experiences deployed in foreign markets; thus, the results obtained are inherently related to the assumptions and data used to make a viable estimation of the economic behavior of an offshore wind project. These assumptions are necessary to carry out more assessments due to the lack of local information. However, the reality is that there are several uncertainties regarding many of the sites associated with an overall low LCOE, which might compromise their viability. For example, many zones in the study area have water depths that exceed those of the projects on which the economic data is based. Additionally, the survivability of the turbines and the viability of their installations and decommission due to extreme environmental conditions can also be limiting factors [68]. Future studies that provide more information regarding the impact of local conditions on an offshore wind project could help to further reduce those uncertainties.

One of the main assumptions made in this study is the complete and widespread availability of connections to the grid along the coast. However, there are no mechanisms in place that provide incentives for new technologies or help to ensure that a project might be connected to the national energy grid. It is essential to account for the absence of incentives hindering the industry in future studies and the reluctance to make any changes in the legal framework to start a new energy project in the sea, or even near the shore. In stark contrast to the experience of other markets that have more incentives, such as feed-in tariffs [22], this might be a new step toward the expansion of the energy market in Chile.

Offshore wind energy provides new opportunities for reducing the impact of climate change on land wind speed, as demonstrated by several models [69]. In addition, future scenarios of offshore wind energy help reduce uncertainty and create an opportunity for exploring new markets associated with renewable energies. In the southern part of Chile, such as in Patagonia, a wind-hydrogen installation based on electrolysis is currently being implemented [70]. The results of this study may help expand this industry to other parts of the country, positioning the northern part of Chile as a hydrogen producer that uses offshore wind energy. This approach takes advantage of the energy-demanding mining activities currently located in the north. As a consequence, it is possible to change the current energy consumption in the country by leveraging renewable energy generation as well as the hydrogen system to produce clean energy.

\section{Conclusions}

The availability of offshore wind energy and the economic viability of an offshore wind farm were estimated along the Chilean territorial sea from 2000 to 2054. The estimations of LCOE ranged from $24 \mathrm{USD} / \mathrm{MWh}$ to almost $2000 \mathrm{USD} / \mathrm{MWh}$, with favorable sites located in approximately $80 \%$ of the study area. However, the Chilean regulatory framework lacks any type of incentives or laws concerning offshore wind energy. The lack of a transministerial legal framework results in several duplications in administrative processes. Consequently, any potential offshore wind project has to deal with several uncertainties regarding its approval and connection to the grid. Increasing the coordination of the public institutions regulating the offshore energy projects would be a necessary step towards 
increasing their viability. Thus, to harness the offshore wind energy potential already present in Chile, the current paradigm governing it must be broken.

Author Contributions: Conceptualization, C.M.; methodology, C.M., F.C.-E. and N.G.A.-d.-L.; software, F.C.-E. and N.G.A.-d.-L.; validation, C.M., F.C.-E. and N.G.A.-d.-L.; formal analysis, C.M., F.C.-E. and N.G.A.-d.-L.; investigation, C.M., F.C.-E. and N.G.A.-d.-L.; writing-original draft preparation, C.M., F.C.-E. and N.G.A.-d.-L.; writing-review and editing, C.M., F.C.-E. and N.G.A.-d.-L.; supervision, C.M.; project administration, C.M.; funding acquisition, C.M. All authors have read and agreed to the published version of the manuscript.

Funding: This research was funded by The Comisión Nacional de Investigación Científica y Tecnológica (Conicyt) de Chile, Fondecyt-Regular 1181155, awarded to Mattar C.

Institutional Review Board Statement: Not applicable.

Informed Consent Statement: Not applicable.

Data Availability Statement: Not applicable.

Acknowledgments: The authors would like to thank ECMWF for the ERA-Interim products, the MODIS team for the land surface products and the National Laboratory of High-Performance Computing (NLHPC).

Conflicts of Interest: The authors declare no conflict of interest.

\section{References}

1. Zhao, F.; Lee, J. Global Wind Report 2019; Global Wind Report; Global Wind Energy Council: Brussels, Belgium, $2020 ;$ p. 78.

2. Ramírez, L.; Fraile, D.; Brindley, G. Offshore Wind in Europe Key Trends and Statistics 2019; Wind Europe: Brussels, Belgium, 2020; p. 40.

3. Argin, M.; Yerci, V.; Erdogan, N.; Kucuksari, S.; Cali, U. Exploring the offshore wind energy potential of Turkey based on multi-criteria site selection. Energy Strategy Rev. 2019, 23, 33-46. [CrossRef]

4. Elsner, P. Continental-scale assessment of the African offshore wind energy potential: Spatial analysis of an under-appreciated renewable energy resource. Renew. Sustain. Energy Rev. 2019, 104, 394-407. [CrossRef]

5. Emeksiz, C.; Demirci, B. The determination of offshore wind energy potential of Turkey by using novelty hybrid site selection method. Sustain. Energy Technol. Assess. 2019, 36, 100562. [CrossRef]

6. Gadad, S.; Deka, P.C. Offshore wind power resource assessment using oceansat-2 scatterometer data at a regional scale. Appl. Energy 2016, 176, 157-170. [CrossRef]

7. Gao, X.; Yang, H.; Lu, L. Study on offshore wind power potential and wind farm optimization in Hong Kong. Appl. Energy 2014, 130, 519-531. [CrossRef]

8. Li, D.; Geyer, B.; Bisling, P. A model-based climatology analysis of wind power resources at 100-m height over the Bohai Sea and the Yellow Sea. Appl. Energy 2016, 179, 575-589. [CrossRef]

9. Mattar, C.; Guzmán-Ibarra, M.C. A techno-economic assessment of offshore wind energy in Chile. Energy 2017, 133, 191-205. [CrossRef]

10. Waewsak, J.; Landry, M.; Gagnon, Y. Offshore wind power potential of the gulf of Thailand. Renew. Energy 2015, 81, 609-626. [CrossRef]

11. Schmela, M.; Rossi, R.; Beauvais, A.; Chevillard, N.; Paredes, M.G.; Heisz, M.; Rossi, R.; Schmela, M. Global Market Outlook For. Solar Power/2019-2023; Global Market Outlook; Solar Power Europe: Brussels, Belgium, 2019.

12. Irena, I. Renewable Power Generation Costs in 2017; International Renewable Energy Agency Abu Dhabi: Abu Dhabi, United Arab Emirates, 2018; p. 160.

13. Morthorst, P.E.; Kitzing, L. Economics of building and operating offshore wind farms. In Offshore Wind Farms; Ng, C., Ran, L., Eds.; Woodhead Publishing: Sawston, UK, 2016; pp. 9-27. ISBN 978-0-08-100779-2.

14. Brown, C.; Poudineh, R.; Foley, B. Achieving a Cost-Competitive Offshore Wind Power Industry: What Is the Most Effective Policy Framework? Oxford Institute for Energy Studies: Oxford, UK, 2015.

15. DeCastro, M.; Salvador, S.; Gómez-Gesteira, M.; Costoya, X.; Carvalho, D.; Sanz-Larruga, F.J.; Gimeno, L. Europe, China and the United States: Three different approaches to the development of offshore wind energy. Renew. Sustain. Energy Rev. 2019, 109, 55-70. [CrossRef]

16. Normann, H.E. Policy networks in energy transitions: The cases of carbon capture and storage and offshore wind in Norway. Technol. Forecast. Soc. Change 2017, 118, 80-93. [CrossRef]

17. McAuliffe, F.D.; Murphy, J.; Lynch, K.; Desmond, C.; Norbeck, J.A.; Nonås, L.M.; Attari, Y.; Doherty, P.; Sorensen, J.D.; Giebhardt, J.; et al. Driving Cost Reductions in Offshore Wind: The Leanwind Project Final Publication; Driving Cost Reduction on Offshore Wind; Leanwind: Brussels, Belgium, 2017; p. 72. 
18. Vieira, M.; Snyder, B.; Henriques, E.; Reis, L. European offshore wind capital cost trends up to 2020. Energy Policy 2019, 129, 1364-1371. [CrossRef]

19. International Energy Agency. World Energy Outlook 2019; International Energy Agency: Paris, France, 2019; ISBN 978-92-64-97300-8.

20. Kafas, A.; Ripken, M.; Wright, K.; Billet, M.; Sangiuliano, S.; Ooms, E.; Scheffler, U. Status Quo Report on Offshore Energy Planning Provisions in the North Sea Region; NorthSEE, A North Sea Perspective on Shipping, Energy and Environment Aspects in MSP; NorthSEE Project: Brussels, Belgium, 2018; p. 76.

21. Musial, W.D.; Beiter, P.C.; Spitsen, P.; Nunemaker, J.; Gevorgian, V. 2018 Offshore Wind Technologies Market Report; National Renewable Energy Lab.: Golde, CO, USA, 2019.

22. Reichardt, K.; Rogge, K. How the policy mix impacts innovation: Findings from company case studies on offshore wind in Germany. Environ. Innov. Soc. Transit. 2016, 18, 62-81. [CrossRef]

23. Costoya, X.; deCastro, M.; Carvalho, D.; Gómez-Gesteira, M. On the suitability of offshore wind energy resource in the United States of America for the 21st century. Appl. Energy 2020, 262, 114537. [CrossRef]

24. Rueda-Bayona, J.G.; Guzmán, A.; Eras, J.J.C.; Silva-Casarín, R.; Bastidas-Arteaga, E.; Horrillo-Caraballo, J. Renewables energies in Colombia and the opportunity for the offshore wind technology. J. Clean. Prod. 2019, 220, 529-543. [CrossRef]

25. Rueda-Bayona, J.G.; Guzmán, A.; Eras, J.J.C. Wind and power density data of strategic offshore locations in the Colombian Caribbean coast. Data Brief 2019, 27, 104720. [CrossRef]

26. De Assis Tavares, L.F.; Shadman, M.; de Freitas Assad, L.P.; Silva, C.; Landau, L.; Estefen, S.F. Assessment of the offshore wind technical potential for the Brazilian southeast and south regions. Energy 2020, 196, 117097. [CrossRef]

27. Pimenta, F.; Kempton, W.; Garvine, R. Combining meteorological stations and satellite data to evaluate the offshore wind power resource of southeastern Brazil. Renew. Energy 2008, 33, 2375-2387. [CrossRef]

28. Gomes, M.S.D.S.; De Paiva, J.M.F.; Moris, V.A.D.S.; Nunes, A.O. Proposal of a methodology to use offshore wind energy on the southeast coast of Brazil. Energy 2019, 185, 327-336. [CrossRef]

29. Mattar, C.; Villar-Poblete, N. Estimación del potencial eólico off-shore en las costas de Chile utilizando datos de escaterómetro y Reanalysis. Revista Teledetección 2014, 41, 49-58. [CrossRef]

30. Simsek, Y.; Lorca, Á.; Urmee, T.; Bahri, P.A.; Escobar, R. Review and assessment of energy policy developments in Chile. Energy Policy 2019, 127, 87-101. [CrossRef]

31. Ministerio de Energía. Propicia La Ampliación de La Matriz Energética, Mediante Fuentes Renovables No Convencionales; Ministerio de Energía: Santiago, Chile, 2013.

32. Ministerio de Energía. Energía 2050 Política Energética de Chile, 2nd ed.; Ministerio de Energía: Santiago, Chile, $2017 ;$ p. 16.

33. De Linaje, N.G.-A.; Mattar, C.; Borvarán, D. Quantifying the wind energy potential differences using different WRF initial conditions on Mediterranean coast of Chile. Energy 2019, 188, 116027. [CrossRef]

34. Mattar, C.; Borvarán, D. Offshore wind power simulation by using WRF in the central coast of Chile. Renew. Energy 2016, 94, 22-31. [CrossRef]

35. Mediavilla, D.G.; Sepúlveda, H.H. Nearshore assessment of wave energy resources in central Chile (2009-2010). Renew. Energy 2016, 90, 136-144. [CrossRef]

36. Muñoz, R.C.; Falvey, M.J.; Arancibia, M.; Astudillo, V.I.; Elgueta, J.; Ibarra, M.; Santana, C.; Vásquez, C. Wind energy exploration over the Atacama desert: A numerical model-guided observational program. Bull. Am. Meteorol. Soc. 2018, 99, $2079-2092$. [CrossRef]

37. CNE Capacidad Instalada de Generación. Available online: http:/ / cne.cloudapi.junar.com/api/v2/datastreams/CAPAC-INSTADE-GENER-TOTAL/data.xls?auth_key=7a392227077e0efbfdb16f843fd12a09bea78210\&download=1 (accessed on 10 January 2021).

38. CNE Proyección de la Demanda en GWh. Available online: http://cne.cloudapi.junar.com/api/v2/datastreams/PROYE-DEDEMAN/data.xls?auth_key=7a392227077e0efbfdb16f843fd12a09bea78210\&download=1 (accessed on 10 January 2021).

39. Ministerio de Minería. Crea el Ministerio de Energía y la Comisión Nacional de Energía; Ministerio de Minería: Santiago, Chile, 1978.

40. Ministerio de Defensa Nacional. Sustituye Reglamento Sobre Concesiones Marítimas; Fijado por Decreto Supremo (m) $\mathrm{n}^{\circ} 2$, de 2005, del Ministerio de Defensa Nacional; Ministerio de Defensa Nacional: Santiago, Chile, 2018; Volume 9.

41. Ministerio de Economía, Fomento y Reconstrucción. Crea la Subsecretaria de Pesca en el Ministerio de Economia, Fomento y Reconstruccion; Ministerio de Economía, Fomento y Reconstrucción: Santiago, Chile, 1985.

42. Ministerio Secretaría General de la Presidencia. Crea el Ministerio, el Servicio de Evaluación Ambiental y la Superintendencia del Medio Ambiente; Ministerio Secretaría General de la Presidencia: Santiago, Chile, 2010.

43. Hersbach, H.; Bell, B.; Berrisford, P.; Hirahara, S.; Horányi, A.; Muñoz-Sabater, J.; Nicolas, J.; Peubey, C.; Radu, R.; Schepers, D.; et al. The ERA5 global reanalysis. Q. J. R. Meteorol. Soc. 2020, 146, 1999-2049. [CrossRef]

44. Bellouin, N.; Collins, W.J.; Culverwell, I.D.; Halloran, P.R.; Hardiman, S.C.; Hinton, T.J.; Jones, C.D.; McDonald, R.E.; McLaren, A.J.; O'Connor, F.M.; et al. The HadGEM2 family of met office unified model climate configurations. Geosci. Model. Dev. 2011, 4, 723-757. [CrossRef]

45. Carvalho, D.; Rocha, A.; Gómez-Gesteira, M.; Silva Santos, C. Potential impacts of climate change on European wind energy resource under the CMIP5 future climate projections. Renew. Energy 2017, 101, 29-40. [CrossRef]

46. Kulkarni, S.; Huang, H.-P. Changes in surface wind speed over North America from CMIP5 model projections and implications for wind energy. Adv. Meteorol. 2014, 2014, 1-10. [CrossRef] 
47. Taylor, K.E.; Stouffer, R.J.; Meehl, G.A. An overview of CMIP5 and the experiment design. Bull. Am. Meteor. Soc. 2012, 93, 485-498. [CrossRef]

48. Beiter, P.; Musial, W.; Smith, A.; Kilcher, L.; Damiani, R.; Maness, M.; Sirnivas, S.; Stehly, T.; Gevorgian, V.; Mooney, M.; et al. A Spatial-Economic Cost-Reduction Pathway Analysis for U.S. Offshore Wind Energy Development from 2015-2030; National Renewable Energy Lab. (NREL): Golden, CO, USA, 2016.

49. Weatherall, P.; Marks, K.M.; Jakobsson, M.; Schmitt, T.; Tani, S.; Arndt, J.E.; Rovere, M.; Chayes, D.; Ferrini, V.; Wigley, R. A new digital bathymetric model of the world's oceans. Earth Space Sci. 2015, 2, 331-345. [CrossRef]

50. Celik, A.N.; Kolhe, M. Generalized feed-forward based method for wind energy prediction. Appl. Energy 2013, 101, 582-588. [CrossRef]

51. De Andrade, C.F.; Neto, H.F.M.; Rocha, P.A.C.; Da Silva, M.E.V. An efficiency comparison of numerical methods for determining weibull parameters for wind energy applications: A new approach applied to the northeast region of Brazil. Energy Convers. Manag. 2014, 86, 801-808. [CrossRef]

52. MHI VestasTM. Offshore Wind Turbines; MHI Vestas Innovations; MHI Vestas Offshore: Aarhus, Denmark, 2020.

53. Mann, H.B. Nonparametric tests against trend. Econometrica 1945, 13, 245-259. [CrossRef]

54. Kendall, M.G. Kendall Rank Correlation Methods; Griffin: London, UK, 1975.

55. Brunetti, M.; Buffoni, L.; Maugeri, M.; Nanni, T. Precipitation intensity trends in northern Italy. Int. J. Climatol. 2000, 20, 1017-1031. [CrossRef]

56. Partal, T.; Kahya, E. Trend analysis in Turkish precipitation data. Hydrol. Process. 2006, 20, 2011-2026. [CrossRef]

57. Niedźwiedź, T.; Twardosz, R.; Walanus, A. Long-term variability of precipitation series in east central Europe in relation to circulation patterns. Theor. Appl. Climatol. 2009, 98, 337-350. [CrossRef]

58. Dadaser-Celik, F.; Cengiz, E. A neural network model for simulation of water levels at the Sultan marshes wetland in Turkey. Wetlands Ecol. Manage. 2013, 21, 297-306. [CrossRef]

59. Soukissian, T.; Karathanasi, F.; Axaopoulos, P.; Voukouvalas, E.; Kotroni, V. Offshore wind climate analysis and variability in the Mediterranean sea. Int. J. Climatol. 2018, 38, 384-402. [CrossRef]

60. Short, W.; Packey, D.; Holt, T. A manual for the economic evaluation of energy efficiency and renewable energy technologies. NASA STI Recon Tech. Rep. N 1995, 95. [CrossRef]

61. Bjerkseter, C.; Ågotnes, A. Levelised Costs of Energy for Offshore Floating Wind Turbine Concepts. Master's Thesis, Norwegian University of Life Sciences, Ås, Norway, 2013.

62. Ministerio de Hacienda. Reforma Tributaria que Modifica el Sistema de Tributación de la Renta e Introduce Diversos Ajustes en el Sistema Tributario; Ministerio de Hacienda: Santiago, Chile, 2014.

63. Ministerio de Energía. Méritos Económicos, Riesgos y Análisis de Competencia En El Mercado Eléctrico Chileno de Las Distintas Tecnologías de Generación de Electricidad; Ministerio de Energía: Santiago, Chile, 2017; p. 136.

64. Valpy, B.; Hundleby, G.; Freeman, K.; Roberts, A.; Logan, A. 57 Technology Innovations That Will Have Greater Impact on Reducing the Cost of Electricity from European Offshore Wind Farms; Future Renewable Energy Costs, Offshore Wind; BVG Associates: Eindhoven, The Netherlands, 2017; p. 100.

65. NREL Offshore Wind. Available online: https://atb.nrel.gov/electricity/2020/index.php?t=ow\#n_xp6rzmy9 (accessed on 10 January 2021).

66. Hundleby, G.; Freeman, K.; Logan, A.; Frost, C. Floating Offshore: 55 Technology Innovations that will Have Greater Impact on Reducing the Cost of Electricity from European Floating Offshore Wind Farms; BVG Associates: Eindhoven, The Netherlands, 2017.

67. Generadoras de Chile. Boletín Del Mercado Eléctrico: Sector Generación; Dirección de Estudios y Contenidos Generadoras de Chile; Generadoras de Chile: Santiago, Chile, 2019; p. 26.

68. Weiss, C.V.C.; Guanche, R.; Ondiviela, B.; Castellanos, O.F.; Juanes, J. Marine renewable energy potential: A global perspective for offshore wind and wave exploitation. Energy Convers. Manag. 2018, 177, 43-54. [CrossRef]

69. Sherman, P.; Chen, X.; McElroy, M. Offshore wind: An opportunity for cost-competitive decarbonization of China's energy economy. Sci. Adv. 2020, 6. [CrossRef] [PubMed]

70. Gallardo, F.I.; Monforti Ferrario, A.; Lamagna, M.; Bocci, E.; Astiaso Garcia, D.; Baeza-Jeria, T.E. A techno-economic analysis of solar hydrogen production by electrolysis in the north of Chile and the case of exportation from Atacama desert to Japan. Int. J. Hydrog. Energy 2020. [CrossRef] 